\title{
BALIKA fact sheet: Highlight on gender and rights
}

Population Council

Follow this and additional works at: https://knowledgecommons.popcouncil.org/departments_sbsr-pgy

Part of the Demography, Population, and Ecology Commons, Family, Life Course, and Society Commons, International Public Health Commons, and the Women's Health Commons How does access to this work benefit you? Let us know!

\section{Recommended Citation}

"BALIKA fact sheet: Highlight on gender and rights." New York: Population Council, 2014. 


\section{Societal values and attitudes are reflected in the} values and attitudes held by adolescent girls. The BALIKA survey included a number of questions to measure the values held about gender equality in terms of marriage expectations, gender roles, masculinity, and acceptance of violence.

- Early marriage and childbearing can exacerbate gender inequitable attitudes by overemphasizing the gender role specialization associated with domestic and child bearing responsibilities.

- Age and experience exert influences on perceptions about societal norms.

\section{GENDER EQUALITY}

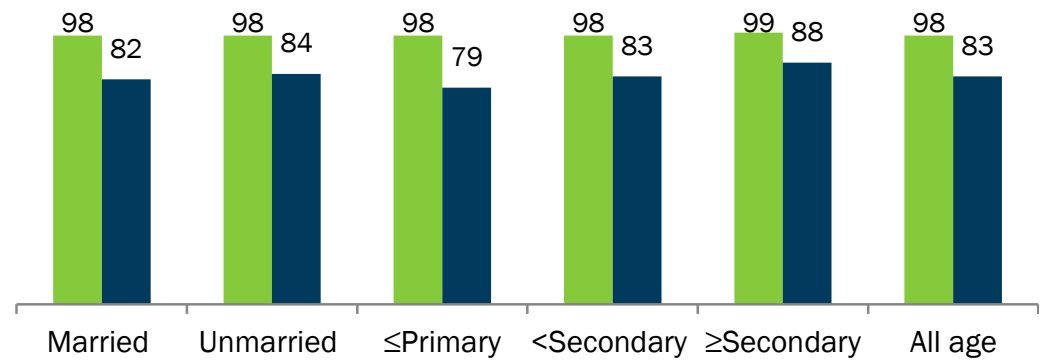

Men and women should be treated equally

- Men should assist with household chores

- Almost all adolescent respondents in the BALIKA survey believed that men and women should be treated equally (98\%). Few adolescents (17\%) perceived that their parents were biased towards their male child in providing more food than girls in the family. Slightly higher percentage of married girls (19\%) compared to unmarried girls and higher number of girls having primary or less education (21\%) reported so. More than $80 \%$ of the adolescents believed that men should assist women with household chores.

\section{HIGHLIGHTS}

- $98 \%$ of girls agreed that girls and boys deserved to be treated equally.

- $83 \%$ of married girls and $75 \%$ of unmarried girls reported that taking care of the family was a woman's primary role.

- $44 \%$ of married girls and $39 \%$ of unmarried girls reported that men should have the final say in all family matters.

- $50 \%$ of married girls reported that a man who beats his wife is justified under certain circumstances.

- $58 \%$ of married girls reported that women should tolerate violence to "preserve the harmony of family life" compared to $47 \%$ of unmarried girls.

- $\mathbf{5 5 \%}$ of girls overall agreed that women should have the right to seek divorce.

- $38 \%$ of girls overall agreed that a wife can refuse to have sex with her husband. 
GIRLS' PERCEIVED ABILITY TO REFUSE

ARRANGED MARRIAGE

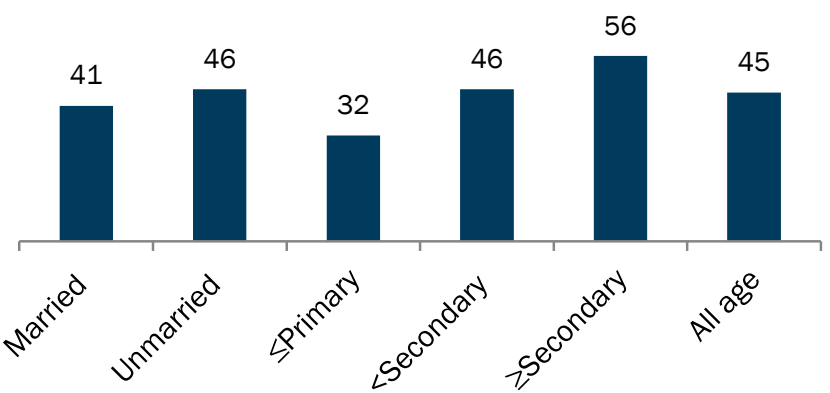

- About $45 \%$ of adolescents agreed that girls could refuse arranged marriage.

- About $41 \%$ of married girls expressed that opinion compared to $46 \%$ of unmarried girls.

- Girls who are more educated expressed the opinion more than less-educated girls.

“When a girl earns and she nears adulthood, then parents do not go against her will so easily. I too had disagreements with my family about my decision to not get married. I talked to them and negotiated. Finally, they agreed that I could live by my own choice since I earn my own living. I argued that there were many people including women who are not married and living a decent life of their own."

-RUBI, 26-YEAR-OLD UNMARRIED WOMAN

GENDER ROLE ATTITUDES: MASCULINITY

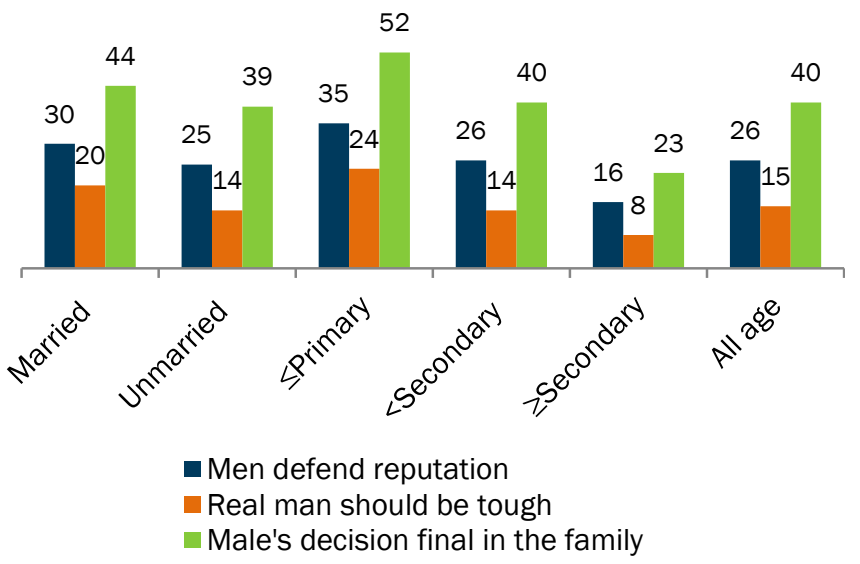

- About one-fourth of adolescents perceived that a man should use force to defend his reputation; married, lesseducated adolescents were more likely to agree with this statement. Similar results were found regarding the notions that "real men should be tough" and "a man's decision is final in the family."
"We (girls) cannot go outside like boys and after school we usually help our mothers in

household chores."

-RITA, 15 YEARS OLD

\section{TOLERATING VIOLENCE}

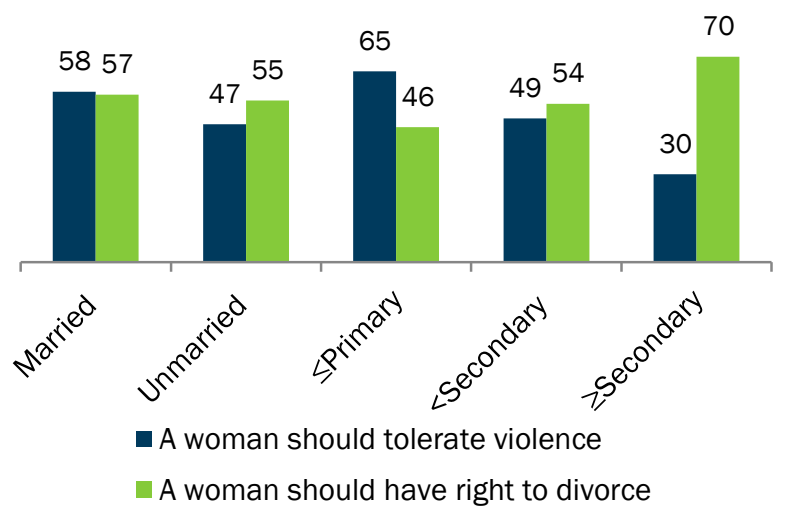

- There was almost no variation in the perception of tolerance of violence by age, but remarkable variation was observed by education level and marital status.

"I cannot tell whether I agree or disagree. Even if something goes against my will, I try to accept it just to preserve the harmony of family life. I got married at a very young age and could not perform household chores properly, thus my mother-in-law used to beat me. She said that they had brought me to do household chores."

-LATA, 17-YEAR-OLD GIRL

\section{CONCLUSION}

The data highlighted here reveal that attitudes regarding gender equitability differ across domains and by the background characteristics of the respondent in terms of education, marital status and age. Those who are married, less educated, and young are less aware of gender equality and rights including domestic violence, autonomy and confidence. The data suggest some specific areas where interventions may produce positive outcomes. Education can change values about gender roles by changing power dynamics and by changing gender-based division of labor. 